\title{
Evaluation of Toxicity of Ethanolic Extracts of Piper guineense and Capsicum annum on Dermestid Beetle, Demestes maculatus (DeGeer 1774), a Pest on Dried Catfish, Clarias gariepinus
}

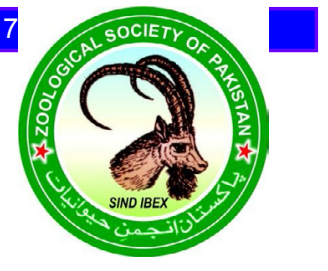

\author{
Felicia Nkechi Ekeh*, Ifeanyi Oscar Ndimkaoha Aguzie, Joy Ihuoma Nzei, \\ Chinenye Maria-Goretti Ohanu, Godwin Ikechukwu Ngwu and Chukwudiebube Ugolo
}

Department of Zoology and Environmental Biology, University of Nigeria, Nigeria

\begin{abstract}
A B S T R A C T
The effectiveness of Piper guineense and Capsicum annum in prevention of Dermestes maculatus infestation on sundried catfish, Clarias gariepinus was studied. Ethanolic extracts of $P$. guineense and $C$. annum fruits were prepared using Soxhlet extractor. In a split-plot design comprising the two extracts in different concentrations, a total of 63 sundried adult $C$. gariepinus of mean weight $111.47 \pm 2.34 \mathrm{~g}$ were randomized into three treatment groups $\mathrm{A}-\mathrm{C}$ for each extract and a control $\mathrm{D}$. The treatment groups were in triplicates with each containing three catfish. The groups contained fish infested with 20 larvae, 20 adults and eggs of $D$. maculatus. Groups $\mathrm{A}-\mathrm{C}$ were exposed to 8,12 and $15 \%(\mathrm{w} / \mathrm{w})$ of extract per kilogram of fish respectively. Observation for mortality and larval emergence was made every 3 days and cumulative taking at the end of 28 days. Mortality of adult D. maculatus was higher in 8,12 and $15 \%$ $(\mathrm{w} / \mathrm{w})$ of $P$. guineense and $15 \%(\mathrm{w} / \mathrm{w})$ of $C$. annum than control. Both extracts significantly enhanced $D$. maculatus larval and adult mortality $(\mathrm{p}<0.05)$. Larval emergence in 8,12 and $15 \%(\mathrm{w} / \mathrm{w})$ of $P$. guineense and $C$. annum were significantly reduced than in the control $(\mathrm{p}<0.05)$. The three concentrations of $P$. guineense and $15 \%(\mathrm{w} / \mathrm{w})$ of $C$. annum lowered weight loss of the fish significantly $(\mathrm{p}<0.05)$. Ethanolic extracts of $P$. guineense and $C$. annum were moderately effective in protection of dried catfish, $C$. gariepinus against D. maculatus infestation.
\end{abstract}

Article Information
Received 28 March 2017
Revised 29 July 2017
Accepted 10 February 2018
Available online 24 May 2018
Authors' Contribution
FNE, JIN, CMO and GIN conceived
the study. IONA and CU performed
the experiment. IONA, FNE, CMO
and JIN performed statistical analysis.
FNE, IONA, CU and GIN wrote the
manuscript.
Key words
Piper guineense, Capsicum annum,
Dermestes maculatus, Clarias
gariepinus, Insecticidal.

\section{INTRODUCTION}

$\mathrm{F}$ ish supplies a good balance of protein, vitamins and minerals (Ufele et al., 2015). Fish protein is known to be the cheapest sources of animal protein (Olayide, 1973). Fish constitute more than $60 \%$ of the total protein intake in adults especially in rural areas (Adeleye, 1992). It provides about $20 \%$ protein and essential amino acids such as lysine and methionine, and it competes favourably with the protein content of egg, milk and meat. The harvesting, handling, processing and distribution of fish provide livelihood for millions of people as well as providing foreign exchange earnings for many countries (Al-Jufaili and Opara, 2006). Dried fish in particular is one of the highly digestible and respectable sources of proteins and essential minerals in the tropics but it is highly prone to insect pest infestation at storage (Odeyemi et al., 2000). It has been estimated that post-harvest losses of between $10 \%$

\footnotetext{
Corresponding author: felicia.ekeh@unn.edu.ng 0030-9923/2018/0004-1313 \$ 9.00/0

Copyright 2018 Zoological Society of Pakistan
}

and $35 \%$ by weight of the world fish catch result from poor handling, processing and storage (Lale and Alaga, 2002).

Dermestes maculatus is the major pest of smoked fish (Eke et al., 2008) and could be controlled by synthesized chemicals (Boeke et al., 2001). However in recent years, there have been increasing and concerted efforts directed at developing natural pest management control agents that are relatively cheap, safe and environment friendly as alternatives to synthesized insecticides (Boeke et al., 2001; Akinwumi et al., 2007; Ilyas et al., 2017). Botanical extracts being alternatives to the use of insecticide in the control of pests have been to an extent efficient in pest management. Teotia and Terwari (1977) noted that insecticides of plant origin were especially valued for application against insect pest of fodder, fruits, vegetable and stored produce because of their high degree of tolerance by mammals. Most of the botanical insecticides that have been tested include guava (Rehin and Espig, 1991) and eucalyptus (Dakshinamurthy, 1988). However, against this background, the aim of this research was to evaluate two botanicals (Piper guineense and Capiscum annum seeds) for the control of dermestid beetle (Dermestes maculatus De Geer) on dried fish. 


\section{MATERIALS AND METHODS}

\section{Collection of dried fish samples}

Samples of dried fish were bought from Ogige market in Nsukka, Enugu State, Nigeria. The fish samples used for the project were not infested at the time of purchase. The dried fish samples were taken to the Entomology Laboratory of the Department of Zoology and Environmental Biology, University of Nigeria, Nsukka, Enugu State.

\section{Dermestes maculatus collection}

Dermestes maculatus were collected from infested stored dried fish by the help of dry fish sellers in Ogige Market, Nsukka, Enugu State. They were all collected into big containers in which the adult males and females were allowed to mate and reproduce. Thereafter, the first generation was collected to infest the pest-free fish samples. The pest used was further confirmed at the Entomology Unit of Zoology and Environmentl Biology, University of Nigeria, Nsukka as Dermestes maculatus.

\section{Collection of plant material and extracts preparation}

Piper guineense and Capiscum annum seeds were collected from Nsukka in Enugu State. The plant samples were identified at Department of Plant Science and Biotechnology, University of Nigeria, Nsukka where voucher samples were kept.

The seeds of the plants were collected in different baskets. They were exposed for seven days to dry at room temperature to avoid the loss of its active compounds. After drying, they were taken to the Department of Crop Science, University of Nigeria, Nsukka for grinding. The powdered form was put in air-tight bottles and stored in refrigerator. Ethanolic extracts of $P$. guineense and $C$. annum seeds were prepared using a Sohxlet apparatus.

\section{Phytochemical analysis}

Phytochemical analysis was done in the Department of Pharmacognosy, Faculty of Pharmaceutical Sciences of the University of Nigeria, Nsukka. Phytochemicals tested for were alkaloids, saponings, glycosides, tannins, steroid, terpenoid, flavonoids and phenols.

\section{Experimental design}

In a split-plot design comprising the two extracts at different concentrations, 63 sun-dried adult $C$. gariepinus catfish of mean eight $111.47 \pm 2.34 \mathrm{~g}$ were randomized into three groups A - C for each extract and a single control $D$. The treatment groups were replicated three times with each containing three catfish. The groups contained fish infested with 20 larvae, 20 adults and eggs of D. maculatus. Groups A-C were exposed to 8, 12 and $15 \%(w / w)$ of extract per kilogram of fish, respectively. Observation for mortality and larval emergence was made every 3 days and cumulative taking at the end of 28 days.

\section{Evaluation of insecticidal activity}

Numbers of dead D. maculatus in the treatment groups were recorded every 3 days for the duration of the study. All the dead insects were removed every 3 days. The insecticidal activity of $P$. guineense and $C$. annum seed extracts were evaluated as percentage $D$. maculatus mortality using the formula:

$$
\text { Mortality (\%) }=\frac{\text { No. of dead C. maculatus }}{\text { Total No.of C. maculatus introduced }} \times 100
$$

\section{Evaluation of larvae emergency}

At the end of 28 days the total number of larvae that emerged was counted. Percentage emergence was calculated using the formula:

$$
\text { Emergence }(\%)=\frac{\text { No. of larvae that emerged }}{\text { No. of eggs laid }} \times 100
$$

\section{Weight loss}

The weight of the fish in each replicate at the commencement (initial weight) and at the end of 28 days (final weight) treatment was taken. From which weight loss was calculated using the formula:

Weight loss $(\%)=\frac{\text { Final weight }- \text { Initial weight }}{\text { Initial weight }} \times 100$

\section{Data analysis}

Data was analysed using Statplus Pro Version v 5.8.9 (AnalystSoft Inc., Walnut, Canada) and Statistical Package for Social Sciences (SPSS) version 20 (IBM Corp., Armonk, New York). Student T-test and two-way Analysis of Variance (ANOVA) was used to compare concentration and duration associated activity of the extract against $D$. maculatus. Level of significance was set at $\mathrm{p}<0.05$.

\section{RESULTS}

\section{Mortality}

Mortality of larvae $D$. maculatus was enhanced by $P$. guineense and C. annum ethanolic extracts (Table I). The performance of $P$. guinnense was not improved by increase in concentration from 8 to $15 \%(\mathrm{w} / \mathrm{w})$. Only $15 \%(\mathrm{w} / \mathrm{w})$ of $C$. annum extract significantly improved $D$. maculatus mortality compared to control. There was no significant difference between equal concentrations of the two extracts in causing mortality of D. maculatus larvae. Mortality of 
adult $D$. maculatus was similarly enhanced on exposure to ethanolic extracts of $P$. guineense and $C$. annum (Table I). The activity of $P$. guineense appears to be concentration dependent; $8 \%$ P. guineense performance was not different from that of control significantly $(\mathrm{p}>0.05)$. There was no significant difference in the performance of $P$. guineense compared to equal concentration of $C$. annum extract ( $\mathrm{p}$ $>0.05)$.

Table I.- Effect of Piper guineense and Capsicum annum extracts on mortality of larvae and adult Dermestes maculatus.

\begin{tabular}{lccc}
\hline $\begin{array}{l}\text { Concentration } \\
(\% \mathbf{\%} / \mathbf{)})\end{array}$ & P. guineense & C. annum & P-value* \\
\hline Larvae (n= 10) & & & \\
Control (0) & $15.67 \pm 4.04^{\mathrm{b}}$ & $15.67 \pm 4.04^{\mathrm{b}}$ & - \\
8 & $32.38 \pm 5.72^{\mathrm{a}}$ & $19.63 \pm 1.59^{\mathrm{b}}$ & 0.098 \\
12 & $35.83 \pm 8.74^{\mathrm{a}}$ & $49.79 \pm 22.80^{\mathrm{b}}$ & 0.598 \\
15 & $49.21 \pm 7.96^{\mathrm{a}}$ & $55.00 \pm 14.40^{\mathrm{a}}$ & 0.650 \\
Adult (n= 10) & & & \\
Control (0) & $15.00 \pm 5.77^{\mathrm{b}}$ & $15.00 \pm 5.77^{\mathrm{b}}$ & - \\
8 & $26.67 \pm 6.01^{\mathrm{ab}}$ & $40.00 \pm 7.64^{\mathrm{a}}$ & 0.152 \\
12 & $38.33 \pm 1.67^{\mathrm{a}}$ & $36.67 \pm 3.26^{\mathrm{a}}$ & 0.670 \\
15 & $40.00 \pm 10.00^{\mathrm{a}}$ & $31.67 \pm 4.01^{\mathrm{a}}$ & 0.191 \\
\hline
\end{tabular}

Values as mean \pm SE. Values with different alphabet superscript in a column were significantly different from DMRT. $* \mathrm{P}-$ value from Student $\mathrm{t}-$ test.

Table II.- Effect of Piper guineense and Capsicum annum extracts on larvae emergence (\%) of Dermestes maculatus.

\begin{tabular}{lccc}
\hline $\begin{array}{l}\text { Concentration } \\
(\% \text { w/w) }\end{array}$ & P. guineense & C. annuum & P-value* \\
\hline Control (0.0) & $60.66 \pm 6.02^{\mathrm{a}}$ & $60.66 \pm 6.02^{\mathrm{a}}$ & \\
8 & $25.85 \pm 1.10^{\mathrm{bc}}$ & $30.07 \pm 1.40^{\mathrm{b}}$ & 0.076 \\
12 & $30.33 \pm 8.36^{\mathrm{b}}$ & $37.51 \pm 5.64^{\mathrm{b}}$ & 0.683 \\
15 & $7.43 \pm 8.43^{\mathrm{c}}$ & $38.33 \pm 9.66^{\mathrm{b}}$ & 0.073 \\
\hline
\end{tabular}

Values as mean \pm SE. Values with different alphabet superscript in a column were significantly different from DMRT. *P - value from Student $\mathrm{t}-$ test.

\section{Larvae emergence}

Emergence of larval $D$. maculatus was inhibited by ethanolic extracts of $P$. guineense and $C$. annum (Table II). Percentage larval emergence of $D$. maculatus was significantly suppressed by 8,12 and $15 \%(\mathrm{w} / \mathrm{w})$ of $P$. guineense and C. annum extracts compared to control ( $\mathrm{p}<$ 0.05). Comparatively, $P$. guineense had better $D$. maculatus larval emergence inhibitory effects than $C$. annum. The D. maculatus larvae emergence inhibitory effect of $P$. guineense was, however, not significantly different from C. annum performance at $\mathrm{p}<0.05$.

\section{Weight Loss}

Percentage weight loss of dried $C$. gariepinus on infestation with $D$. maculatus for 28 days was minimal $(<12 \%)$. Treatment of infested sundried fish with $P$. guineense and $C$. annum lowered weight loss (Fig. 1). P. guineense caused significant reduction in fish weight loss at 8 and $15 \% \mathrm{w} / \mathrm{w}$; only at $15 \% \mathrm{w} / \mathrm{w}$ was the performance of $C$. annum against weight loss in fish significant $(\mathrm{p}<$ $0.05)$. Weight loss was not significantly different between same concentrations of the extracts $(p>0.05)$.

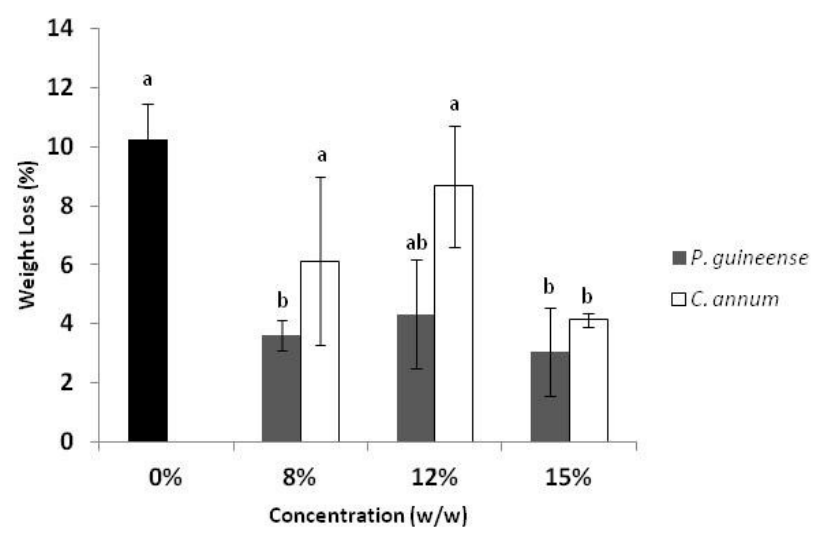

Fig. 1. Weight loss of dried fish after treatment of Dermestes maculatus infestation by $P$. guineense and $C$. annum extracts. Compared to the control $(0 \%)$ percentage weight loss with different alphabet label was significantly different $(\mathrm{p}<0.05)$.

\section{Proximate composition of sundried fish}

The proximate composition of sundried C. gariepinus before and after treatment with the ethanolic extracts of $P$. guineense and $C$. annum are presented in Table III. Initial proximate composition before infestation and after infestation with $D$. maculatus and treatment with concentration of the extracts are given.

Phytochemical composition of Piper guineense and Capsicum annum

The phytochemicals tannin, flavonoids, alkaloids, steroids, saponin, terpenoids and cardiac glycosides were isolated from $P$. guineense (Table IV). Steriods and cardiac glycosides were abundant while tannin, flavonoids, alkaloids and terpenoids were in moderate concentrations. Less number of phytochemicals namely tannin, flavonoids, alkaloids, saponin and terpenoids were isolated from C. annum. Only alkaloid and saponin were in moderate concentration in C. annum. 
Table III.- Effect of Piper guineense and Capsicum annum extracts on proximate composition of the dried fish before and after treatment.

\begin{tabular}{lccc}
\hline & \multicolumn{3}{c}{ Extracts concentration } \\
\cline { 2 - 4 } & $\mathbf{8 \%}$ & $\mathbf{1 2 \%}$ & $\mathbf{1 5 \%}$ \\
\hline Protein & & & \\
$\quad$ Initial (\%) & $69.18 \pm 1.41$ & $74.20 \pm 1.81$ & $60.36 \pm 1.30$ \\
Pg Final (\%) & $67.16 \pm 1.95$ & $65.18 \pm 0.68$ & $69.18 \pm 1.35$ \\
$\quad$ Cpa Final (\%) & $63.31 \pm 0.42$ & $70.32 \pm 0.43$ & $54.05 \pm 0.19$ \\
Carbohydrate & & & \\
$\quad$ Initial (\%) & $3.78 \pm 0.50$ & $0.73 \pm 0.55$ & $7.86 \pm 0.72$ \\
$\quad$ Pg Final (\%) & $1.79 \pm 0.22$ & $6.43 \pm 0.38$ & $11.17 \pm 0.39$ \\
$\quad$ Cpa Final (\%) & $4.81 \pm 0.35$ & $0.59 \pm 0.48$ & $5.87 \pm 0.91$ \\
Fat & & & \\
$\quad$ Initial (\%) & $0.67 \pm 1.73$ & $0.68 \pm 0.34$ & $0.42 \pm 0.18$ \\
$\quad$ Pg Final (\%) & $4.34 \pm 0.23$ & $5.64 \pm 0.53$ & $1.78 \pm 0.43$ \\
$\quad$ Cpa Final (\%) & $0.64 \pm 1.71$ & $0.65 \pm 1.03$ & $0.44 \pm 0.39$ \\
Fibre & & & \\
$\quad$ Initial (\%) & $0.71 \pm 0.32$ & $0.48 \pm 0.33$ & $0.56 \pm 0.41$ \\
$\quad$ Pg Final (\%) & $3.27 \pm 0.34$ & $3.27 \pm 0.34$ & $1.56 \pm 0.16$ \\
$\quad$ Cpa Final (\%) & $0.63 \pm 0.21$ & $0.58 \pm 0.11$ & $0.40 \pm 0.37$ \\
Ash & & & \\
$\quad$ Initial (\%) & $5.25 \pm 0.37$ & $5.35 \pm 0.39$ & $5.78 \pm 0.33$ \\
$\quad$ Pg Final (\%) & $14.86 \pm 1.79$ & $9.92 \pm 0.73$ & $10.47 \pm 0.56$ \\
$\quad$ Cpa Final (\%) & $22.41 \pm 0.44$ & $14.38 \pm 0.98$ & $19.05 \pm 0.90$ \\
Moisture & & & \\
$\quad$ Initial (\%) & $16.10 \pm 0.84$ & $19.17 \pm 2.14$ & $31.14 \pm 1.01$ \\
Pg Final (\%) & $10.18 \pm 0.19$ & $10.78 \pm 0.65$ & $10.79 \pm 0.53$ \\
$\quad$ Cpa Final (\%) & $13.50 \pm 2.33$ & $16.34 \pm 1.82$ & $18.26 \pm 0.12$ \\
\hline
\end{tabular}

Pg, Piper guineense; Cpa, Capsicum annum.

Table IV.- Phytochemical analysis of Piper guineense and Capsicum annum.

\begin{tabular}{lcc}
\hline Phytochemical & Piper guineense & Capsicum annum \\
\hline Tannin & ++ & + \\
Flavonoid & ++ & + \\
Alkaloid & ++ & ++ \\
Steriods & +++ & - \\
Saponin & + & ++ \\
Terpenoids & ++ & + \\
Cardiac glycosides & +++ & - \\
\hline
\end{tabular}

+++, abundant; ++, moderate; +, little; -, absent.

\section{DISCUSSION}

The efficacy of plant materials and other chemicals as insect control agents are measured directly in terms of abilities to cause mortality of insects, reduction in insect reproductive efficiency (such as reduction in larvae emergence from eggs, and reduction of imago emergence from larvae or pupa), and insect repellency. Indirectly, reduction in damage to infested material measured as number of holes borne into the material, weight or nutrient loss by the material, etc. may be used. The plant materials used had disparate activities in the aspects considered. Both plant extracts performed moderately as insecticidal against larva and adult $D$. maculatus. Insecticidal activities were recorded against larvae and adult $D$. maculatus.

Toxicity of $P$. guineense has been attributed by various authors to their pungent and peppery taste which could asphyxiate insects by blocking the spiracles (Ufele et al., 2015). The presence of bioactive ingredients such as alphapinene, limonene and Linalool in $P$. guineense is a major contributor to their toxic properties against insects (Golob et al., 1999). Similar observation have also been made by Adedire and Lajide (1998) that plant materials within the family Piperaceae to which $P$. guineense belongs have been reported to possess some form of insecticidal properties against eggs of cowpea storage pest, Bruchid, and also capable of suppressing various developmental instars of Callosobruchus maculatus. C. annum seed have been reported to possess insecticidal activities against adults $C$. maculatus and Sitophilus zeamais (Oni, 2010; Mailafiya et al., 2014), larvae Anopheles stephensi and Culex quinquefasciatus (Madhumathy et al., 2007). The insect control performance of $C$. annum and other Capsicum (Solanacae) is due to the presence of seven capsinoids including capsaicin and hydrocapsain (Madhumathy et al., 2007; Oni, 2010).

The low emergence of larvae $D$. maculatus from sundried $C$. gariepinus treated with $P$. guineense and $C$. annum could be due to the presence of alkaloid, steroid and cardiac galacosides groups. Similar observations have been reported by some authors on the disruptive effect of $P$. guineense and $C$. annum. Akinwumi et al. (2007) reported that pulverized plant materials from $P$. guineense inhibited egg hatchability and adult emergence of D. maculatus in smoked catfish (C. gariepinus) during storage. The resultant decreased emergence observed on dried fish treated with the $P$. guineense could be due to high toxic effect of these products on both egg, larval and adult stages of D. maculatus. At the end of four weeks, appreciable difference in weight loss by the dried catfish noticed between the groups treated with the extracts and those untreated may have resulted from the reduction in the number of $D$. maculatus infestation in the infested fish. The short duration of treatment probably caused the minimal observed difference in weight loss generally. Longer duration of treatment would probably have caused more appreciable weight reduction untreated dried catfish than the treated. 


\section{CONCLUSION}

P. guineense and $C$. annum have insecticidal potential against adult $D$. maculatus. The protective and toxic effects of $P$. guineense and $C$. аnnum in addition to local availability make them attractive material in upgrading traditional post-harvest protection practices. The effectiveness of $P$. guineense and $C$. annum in reducing damage and controlling $D$. maculatus infestation in sundried catfish, C. gariepinus during storage could be employed as a possible means of ensuring a steady supply of good quality dried fish.

Statement of conflict of interest

Authors have declared no conflict of interest.

\section{REFERENCES}

Adedire, C.O. and Lajide, L., 1999. Toxicity and oviposition deterrency of some plants extracts on cowpea storage Bruchid, Callosobruchus maculatus Fabricius. J. Pl. Dis. Protect., 106: 647653.

Adeleye, O.A., 1992. Conservation needs of fisheries resources and reorientation for sustainable capture and culture practices. Proceedings of the $10^{\text {th }}$ annual Conference Fisheries Societies of Nigeria, pp. 230-234.

Akinwumi, F.O., Fasakin, E.A. and Adedire, C.O., 2007. Toxic and repellence activities of four plant extracts to Dermestes maculatus De Geer on smoked African mud catfish, Clarias gariepinus Burchell. J. Ent., 4: 149-154. https://doi.org/10.3923/je.2007.149.154

Al-Jufaili, M.S. and Opara, L.U., 2006. Status of fisheries post harvest industry in the sultanate of Oman: part 1 handling and marketing system of fresh fish. J. Fish. Int., 1: 144-149.

Boeke, S.J., Van-Lon, J.J.A., Van-Huis, A., Kossou, D.K. and Dicke, M., 2001. The use of plant materials to protect stored leguminous seeds against seed beetles. Backhuys Publisher, The Netherlands, pp. 108 .

Dakshinamurthy, A., 1988. Effects of certain plant products on storage pest of paddy. Trop. Sci., 28: 119-122.

Eke, F.N., Ekechukwu, N.E. and Onah, I., 2008. Arthropod posts of dried fish and fish byproducts in a tropical urban community market. Anim. Res. Int., 5: 900-903.

Golob, O.J., Mwumbola, V. and Ngulube, F., 1999. The use of locally available materials as Protectants of Maize grains against Insects Infestation during storage in Malawi. J. Stored Prod. Resour., 18: 6774. https://doi.org/10.1016/0022-474X(82)90004-2 IIyas, A., Khan, H.A.A. and Qadir, A., 2017. Effect of leaf extracts of indigenous plants on settling and oviposition responses of peach fruit fly, Bactrocera zonata (Diptera: Tephritidae). Pakistan J. Zool., 49: 1547-1553.

Lale, N.E.S. and Alaga, K.A., 2002. Exploring the insecticidal, larvicidal and repellant properties of Piper guineense Schum and Thonn seed oil for the control of rust - red flour beetle Tribolium castaneum (Herest) in stored Pearl millet, Pennistum glaucum (L). J. biol. Sci., 7: 1215-1220.

Madhumathy, A.P., Ali-Ashraf, A. and Vijayan, V.A., 2007. Larvicidal efficiency of Capsicum annum against Anopheles stephensi and Culex quinquefasciatus. J. Vector Borne Dis., 44: 223226.

Mailafiya, D.M., Maina, F.M., Degri, M.M. and Sharah, H.A., 2014. Bioefficacy of Allium sativum (L.) oil and Capsicum annum Miller (chilli pepper) fruit powder against Callosobruchus maculatus (F.) (Coleoptera: Bruchidae) infestation in stored cowpea grains. Agric. Forest. Fish., 3: 257-263.

Odeyemi, O.O., Owoade, R.A. and Akinkurolere, R., 2000. Toxicity and population suppression effects of Paskia clappertonia on dried fish pest (Dermestes maculatus). Glob. J. Pure appl. Sci., 6: 191-195.

Olayide, S.O., 1973. A quantitative study of food equipment, supply and demand in Nigeria. UI Press, Nigeria, pp. 133.

Oni, M.O., 2010. Evaluation of seed and fruit powders of Capsicum annum and Capsicum frutescens for control of Callosobruchus maculatus (F.) in stored cowpea and Sitophilus zeamais (Motsch) in stored maize. Int. J. Biol., 3: 185-188.

Rehin, S. and Espig, G., 1991. The cultivated plants of the dried fish trade in Nigeria with particular reference to Lake Chad. Trop. Stored Prod. Info., 5: 162-167.

Teotia, T.P.S. and Tewari, G.C., 1997. Insecticidal properties of drupes of Dharek, (Melia azedrachta) and rhizomes of sweet flag (Acorus calamus) against adults of Sitatroga cerelia (Oliver). Indian J. Ent., 39: 222-227.

Ufele, A.W., Ogbumuo, P.N., Ezeonyejiaku, D.C., Mogbo, T.C., Ebenebe, C.I. and Aziagba, B.O., 2015. Evaluation of insecticidal efficacy of Piper guineense on fish beetle (Dermestes maculatus). Am. J. BioSci., 3: 41-45. https://doi.org/10.11648/j. ajbio. 20150302.13 